\title{
MORPHO-GENETIC INSIGHTS IN BREAD WHEAT (TRITICUM AESTIVUM L.) TO COMBAT PECULIAR WATER STRESS CONDITIONS
}

\author{
LUQMAN, M. ${ }^{*}$ - IQBAL, M. \\ Department of Plant Breeding \& Genetics, University College of Agriculture \& Environmental \\ Sciences, The Islamia University of Bahawalpur, Bahawalpur, Pakistan \\ *Corresponding author \\ e-mail:luqmanmirza@hotmail.com \\ (Received 24 $4^{\text {th }}$ Jun 2020; accepted 17th Sep 2020)
}

\begin{abstract}
The present research was undertaken to estimate the yield traits genetics of wheat in normal and water stress conditions. Six lines and three testers were crossed according to line $\times$ tester mating fashion to develop eighteen crosses. Results depicted that variances due to genotypes and crosses were significant for all studied traits in both conditions. Significant differences between lines were witnessed for Plant height $(\mathrm{cm})$, grains spike ${ }^{-1}$ and biological yield plant ${ }^{-1}$ under normal but significant for grains spike $^{-1}$ under water stress condition. Chakwal 86 possessed the highest general combining ability for number of tillers plant ${ }^{-1}$, biological yield plant ${ }^{-1}$ and grain yield plant ${ }^{-1}$ in both conditions. Similarly, in both conditions, the best specific cross combinations were B 215 B $1103 \times$ Galaxy 2013 and GA $2002 \times$ 2511. Gene action was studied to evaluate the nature for inheritance of evaluated traits. All the observed traits reflected non-additive type of gene action except grains spike ${ }^{-1}$ under both conditions. High heritability $\left(\mathrm{H}^{2}\right)$ under both conditions was witnessed for plant height, flag leaf area, tillers plant ${ }^{-1}$, grains spike $^{-1}$ and biological yield plant ${ }^{-1}$. The genotypes Chakwal 86, Galaxy 2013 and crosses B 215 B $1103 \times$ Galaxy 2013 and GA $2002 \times 2511$ can be used in future for developing high yielding wheat varieties under water stress conditions.
\end{abstract}

Keywords: line $\times$ tester, combining ability, gene action, heritability

\section{Introduction}

Wheat is grown almost all over the globe with a total production of 732.40 million tonnes. Major wheat producing countries include the European Union (136.86 million tonnes), China (131.43 million tonnes), India (99.87 million tonnes), Russia (71.69 million tonnes), United States (51.29 million tonnes), Canada (32.20 million tonnes) and Pakistan having production of 25.20 million tonnes (FAO, 2019). Wheat occupies a major place in the economic system of Pakistan and shares $8.9 \%$ value addition in agriculture and adds $1.6 \%$ to GDP of Pakistan. Production of wheat reached 25.195 million tonnes during 2018-19 with an increase of 119 million tonnes over 25.076 million tonnes during 2017-18 (Ministry of Food, Agriculture and Livestock, 2019).

Currently, the population of Pakistan is more than 210 million and is growing at a fast pace causing an increase in food demand. Therefore, we need to develop wheat varieties that can give better production even with less water requirement (Noorka et al., 2013). Scarcity of water is a global issue due to shrinkage of fresh water resources. It is a major concern for plant breeders to encounter various kinds of drought (HongBo et al., 2006). Different yield associated traits like plant height, spikelets spike, spike length, 1000-grain weight and grains per spikes are considerably reduced by water stress (Mirbahar et al., 2009; Noorka and Teixeira da Silva, 2014). We can enhance our overall production of wheat by improving our existing varieties by better utilization of available germplasm resources and breeding techniques (Ullah 
et al., 2019). For checking the yield barrier levels and make wheat cultivation more attractive, it has now become necessary to explore alternative approaches. Among the potential alternatives, an important access for increasing wheat production has been the search for a desirable cross combination which can withstand vagaries of climate change (Noorka et al., 2013). The study of combining ability and heritability are important pre-requisites for a sound crop improvement program following conventional hybridization. Several mating designs have been used in different crop plants for estimating combining ability effects of the parents and identification of desirable genotypes for the production of hybrid. These designs provide information on various genetic parameters of variance. The line $\times$ tester mating technique designed by Kempthorne (1957; Noorka and Taufiqullah, 2015) appears to be an effective method to evaluate diverse genotypes for assessing their combining ability effects. The design has an added advantage of its application in a situation of complete set of crosses. Different types of gene actions are estimated from combining ability variances which direct the manifestation of yield and yield relating parameters (Dreisigacker et al., 2005). Additionally, comprehensive information about the association among parents and hybrids is necessary to improve wheat hybrid breeding program (Longin et al., 2012; Noorka et al., 2020).

Keeping in view, the current research was commenced to identify the potential parents, crosses and their segregates for viable breeding program and to estimate the combining ability effects of parents and crosses both under normal and water stress conditions.

\section{Materials and methods}

\section{Research areas}

The present investigation was undertaken at experimental area of the Department of Plant Breeding and Genetics, University College of Agriculture and Environmental Sciences, The Islamia University of Bahawalpur, Pakistan (the latitude of Bahawalpur, Pakistan is 29.39, and the longitude is 71.68; Bahawalpur is located with the GPS coordinates of $29^{\circ} 24^{\prime} \mathrm{N}$ and $71^{\circ} 40^{\prime} \mathrm{E}$; Table 1) during the year 2016-17 by using six wheat genotypes as lines (Chakwal 86, BARS 2009, Chakwal 50, GA 2002, ESWYT P117 and B215 B1103) and three genotypes as testers (Galaxy 2013, 2511 and Lasani 2008). These six lines (females) and three testers (males) were crossed according to line $\times$ tester mating design to develop eighteen crosses.

\section{Experimental details}

During the year 2017-18, the $\mathrm{F}_{0}$ seeds of eighteen crosses along with their parents were planted to develop $F_{1}$ under both environmental conditions in randomized complete block design (RCBD) with three replications. Plant to plant and row to row distance was maintained as $15 \mathrm{~cm}$ and $30 \mathrm{~cm}$, respectively. All recommended cultural practices were applied for both environmental conditions except non application of irrigation at tillering stage for water stress environment. When the plants reached maturity, data of ten guarded plants for each genotype of normal and water stress conditions were taken for morphological traits like plant height $(\mathrm{cm})$, flag leaf area $\left(\mathrm{cm}^{2}\right)$, tillers plant ${ }^{-1}$, spike length $(\mathrm{cm})$, grains spike ${ }^{-1}, 1000$-grain weight, biological yield plant ${ }^{-1}$ and grain yield plant ${ }^{-1}$. 
Table 1. Monthly minimum, maximum, average temperature and total rainfall

\begin{tabular}{c|c|c|c|c}
\hline Month & $\begin{array}{c}\text { Temperature } \\
\left(\text { Minimum }^{\circ} \mathbf{C} \text { ) }\right.\end{array}$ & $\begin{array}{c}\text { Temperature } \\
\left(\text { Maximum }^{\circ} \mathbf{C} \text { ) }\right.\end{array}$ & $\begin{array}{c}\text { Temperature } \\
\left(\text { Average }^{\circ} \mathbf{C} \text { ) }\right.\end{array}$ & $\begin{array}{c}\text { Rainfall } \\
\left(\text { Average }^{\text {mm })}\right.\end{array}$ \\
\hline December 2017 & 15 & 25 & 19 & 6.88 \\
January 2018 & 14 & 24 & 18 & 0.00 \\
February 2018 & 16 & 27 & 21 & 0.17 \\
March 2018 & 21 & 34 & 27 & 0.02 \\
April 2018 & 26 & 38 & 32 & 2.77 \\
May 2018 & 32 & 43 & 38 & 3.65 \\
\hline
\end{tabular}

\section{Statistical analysis}

Analyses of variances (ANOVA) were performed according to Steel et al. (1997). The general combining ability (GCA) of lines and testers and specific combining ability (SCA) of crosses were worked out by using line $\times$ tester mating technique as suggested by Kempthorne (1957). The ANOVA for Line $\times$ Tester used in the experiment is given in Table 2. Falconer (1989) formula was used to calculate broad sense heritability as under:

$$
\mathrm{H}^{2}=\mathrm{V}_{\mathrm{G}} / \mathrm{V}_{\mathrm{P}}
$$

where: $\mathrm{H}^{2}=$ broad sense heritability, $\mathrm{V}_{\mathrm{G}}=$ genotypic variance, $\mathrm{V}_{\mathrm{P}}=$ phenotypic variance.

Table 2. Analysis of variance (ANOVA) for line $\times$ tester

\begin{tabular}{c|c|c}
\hline Source of variation & Degree of freedom & Mean square \\
\hline Replication $(r)$ & $(r-1)$ & \\
Genotypes $(g)$ & $(g-1)$ & $\mathrm{MS}_{2}$ \\
Parents $(p)$ & $(p-1)$ & \\
Parents versus crosses & $(c-1)$ & \\
Crosses $(c)$ & $(l-1)$ & $M_{l}$ \\
Lines $(l)$ & $(t-1)$ & $M_{t}$ \\
Testers $(t)$ & $(l-1)(t-1)$ & $M_{1 \times t}$ \\
Lines $\times$ testers & $(r-1)(t-1)$ & $\mathrm{MS}_{1}$ \\
Error &
\end{tabular}

$\mathrm{MS}_{2}=$ genotypic mean square, $M_{l}=$ line mean square, $M_{t}=$ tester mean square, $M_{1 \times t}=$ line $\times$ tester mean square, $\mathrm{MS}_{1}=$ error mean square

\section{Results and discussion}

\section{Line $\times$ tester - analysis of variance $(A N O V A)$}

The analysis of variance was worked out for Plant height $(\mathrm{cm})$, flag leaf area $\left(\mathrm{cm}^{2}\right)$, tillers plant ${ }^{-1}$, spike length $(\mathrm{cm})$, grains spike ${ }^{-1}, 1000$-grain weight $(\mathrm{g})$, biological yield plant $^{-1}(\mathrm{~g})$ and grain yield plant ${ }^{-1}(\mathrm{~g})$ for testing the differences among treatments. The mean sums of squares (MSS) for all the studied traits are reflected in Table 3a-d. The results depicted that the variances due to genotypes were significant for all the traits under both conditions. The variability present among hybrids is very useful in improvement of wheat varieties for water stress condition. Significant variation among 
yield related traits has also been reported by Nawaz et al. (2013), Singh et al. (2014), Yao et al. (2014), Salman et al. (2014) and Saeed et al. (2016).

Table 3a. Analysis of variance through $L \times T$ for studied traits under normal and water stress conditions

\begin{tabular}{c|c|c|c|c|c}
\hline \multirow{2}{*}{ Source of variance } & \multirow{2}{*}{$\begin{array}{c}\text { Degree of } \\
\text { freedom }\end{array}$} & \multicolumn{2}{|c|}{ Plant height } & \multicolumn{2}{c}{ Flag leaf area } \\
\cline { 3 - 6 } & 2 & Normal & Water stress & Normal & Water stress \\
\hline Replications & 26 & $133.05^{* *}$ & 0.26 & 3.30 & 2.12 \\
Genotypes & 8 & $43.49^{* *}$ & $41.23 * *$ & $40.54 * *$ & $37.09 * *$ \\
Parents & 17 & $152.97 * *$ & $81.08^{* *}$ & $24.88^{* *}$ & $27.50^{* *}$ \\
Crosses & 1 & $510.86^{* *}$ & $160.98^{* *}$ & 0.27 & 1.17 \\
Parents vs crosses & 5 & $347.98^{* *}$ & 132.76 & 26.50 & 22.65 \\
Lines & 2 & $78.59^{* *}$ & $54.74 * *$ & $30.46^{* *}$ & $25.18^{* *}$ \\
Testers & 10 & $70.34 * *$ & $60.51 * *$ & $22.95 * *$ & $30.39 * *$ \\
Line $\times$ tester & 52 & 1.60 & 2.91 & 0.75 & 0.71 \\
Error & &
\end{tabular}

Table 3b. Analysis of variance through $L \times T$ for studied traits under normal and water stress conditions

\begin{tabular}{c|c|c|c|c|c}
\hline \multirow{2}{*}{ Source of variance } & \multirow{2}{*}{$\begin{array}{c}\text { Degree of } \\
\text { freedom }\end{array}$} & \multicolumn{2}{|c|}{ Tillers plant $^{-1}$} & \multicolumn{2}{c}{ Spike length } \\
\cline { 3 - 6 } & 2 & Normal & Water stress & Normal & Water stress \\
\hline Replications & 1.53 & 0.62 & 0.94 & 0.21 \\
Genotypes & 26 & $8.19^{* *}$ & $6.51^{* *}$ & $1.32^{* *}$ & $1.05^{* *}$ \\
Parents & 8 & $7.49^{* *}$ & $6.24^{* *}$ & $1.58^{* *}$ & $1.40^{* *}$ \\
Crosses & 17 & $8.90^{* *}$ & $6.97^{* *}$ & $1.12^{* *}$ & $0.94^{* *}$ \\
Parents vs crosses & 1 & 1.64 & 0.74 & $2.62^{* *}$ & 0.01 \\
Lines & 5 & 9.73 & 7.67 & 1.35 & 1.11 \\
Testers & 2 & $18.76^{* *}$ & $11.92^{* *}$ & 0.05 & 0.14 \\
Line $\times$ tester & 10 & $6.51^{* *}$ & $5.63^{* *}$ & $1.21^{* *}$ & $1.02^{* *}$ \\
Error & 52 & 0.33 & 0.26 & 0.25 & 0.07 \\
\hline
\end{tabular}

Table 3c. Analysis of variance through $L \times T$ for studied traits under normal and water stress conditions

\begin{tabular}{c|c|c|c|c|c}
\hline \multirow{2}{*}{ Source of variance } & \multirow{2}{*}{$\begin{array}{c}\text { Degree of } \\
\text { freedom }\end{array}$} & \multicolumn{2}{|c|}{ Grains spikes $^{-1}$} & \multicolumn{2}{c}{ 1000-grain weight $(\mathbf{g})$} \\
\cline { 3 - 6 } & 2 & Normal & Water stress & Normal & Water stress \\
\hline Replications & 0.56 & 0.54 & 14.20 & 1.93 \\
Genotypes & 26 & $128.44^{* *}$ & $77.79^{* *}$ & $10.44^{* *}$ & $16.56^{* *}$ \\
Parents & 8 & $78.10^{* *}$ & $46.61^{* *}$ & 8.65 & $16.78^{* *}$ \\
Crosses & 17 & $159.64^{* *}$ & $96.66^{* *}$ & $11.89^{* *}$ & $17.02^{* *}$ \\
Parents vs crosses & 1 & 0.58 & $6.52^{* *}$ & 0.03 & $6.92^{* *}$ \\
Lines & 5 & $527.82^{* *}$ & $319.85^{* *}$ & 16.15 & 18.07 \\
Testers & 2 & $13.71^{* *}$ & $9.42^{* *}$ & 17.98 & $20.65^{* *}$ \\
Line $\times$ tester & 10 & $4.74^{* *}$ & $2.51^{* *}$ & 8.55 & $15.76^{* *}$ \\
Error & 52 & 1.78 & 0.90 & 4.78 & 0.40 \\
\hline
\end{tabular}


Table 3d. Analysis of variance through $L \times T$ for studied traits under normal and water stress conditions

\begin{tabular}{|c|c|c|c|c|c|}
\hline \multirow{2}{*}{ Source of variance } & \multirow{2}{*}{$\begin{array}{l}\text { Degree of } \\
\text { freedom }\end{array}$} & \multicolumn{2}{|c|}{ Biological yield plant $^{-1}(\mathrm{~g})$} & \multicolumn{2}{|c|}{ Grain yield plant $^{-1}(\mathrm{~g})$} \\
\hline & & Normal & Water stress & Normal & Water stress \\
\hline Replications & 2 & 6.19 & 1.72 & 3.47 & 1.05 \\
\hline Genotypes & 26 & $107.54 * *$ & $68.91 * *$ & $26.99 * *$ & $12.77 * *$ \\
\hline Parents & 8 & $139.58 * *$ & $70.93^{* *}$ & $35.24 * *$ & $17.63^{* *}$ \\
\hline Crosses & 17 & $88.93 * *$ & $70.43^{* *}$ & $24.60 * *$ & $10.94 * *$ \\
\hline Parents vs crosses & 1 & $167.44 * *$ & $26.89 * *$ & 1.85 & $4.91 * *$ \\
\hline Lines & 5 & $203.30 * *$ & 115.48 & 19.00 & 7.40 \\
\hline Testers & 2 & $124.06^{* *}$ & $86.69^{* *}$ & $13.48^{* *}$ & $8.52 * *$ \\
\hline Line $\times$ tester & 10 & $24.73 * *$ & $44.65^{* *}$ & $29.62 * *$ & $13.20^{* *}$ \\
\hline Error & 52 & 1.72 & 1.08 & 2.07 & 0.58 \\
\hline
\end{tabular}

\section{Mean variability, general combining ability and specific combining ability}

\section{Mean variability}

Among parents for plant height, the variation was between $102.27 \mathrm{~cm}$ (Chakwal $86)$ to $114.67 \mathrm{~cm}$ (GA 2002) under normal condition while mean values ranged from $68.23 \mathrm{~cm}$ (Galaxy 2013) to $80.36 \mathrm{~cm}$ (Chakwal 86) under water stress condition. Among crosses, this range varied from $90.61 \mathrm{~cm}($ BARS $2009 \times 2511)$ to $114.33 \mathrm{~cm}$ (GA $2002 \times$ Galaxy 2013) under normal whereas under water stress condition, the mean performance ranged from $63.92 \mathrm{~cm}$ (BARS $2009 \times$ Galaxy 2013) to $78.39 \mathrm{~cm}$ $($ B215 B $1103 \times 2511)$. Among parents for flag leaf area, the mean performance was witnessed between $29.56 \mathrm{~cm}^{2}$ (ESYWT P 117) to $40.90 \mathrm{~cm}^{2}$ (B $215 \mathrm{~B} \mathrm{1103)} \mathrm{for} \mathrm{this}$ parameter under normal condition while mean performance ranged from $23.12 \mathrm{~cm}^{2}$ (ESYWT P 117) to $33.46 \mathrm{~cm}^{2}$ (B 215 B 1103) under water stress condition. However, among crosses, the mean value varied from $31.81 \mathrm{~cm}^{2}$ (ESYWT P $117 \times$ Lasani 2008) to $41.56 \mathrm{~cm}^{2}$ (B $215 \mathrm{~B} 1103 \times$ Galaxy 2013) under normal condition whereas the mean performance ranged from $22.24 \mathrm{~cm}^{2}$ (B $215 \mathrm{~B} 1103 \times$ Lasani 2008$)$ to $34.32 \mathrm{~cm}^{2}$ (B 215 B $1103 \times$ Galaxy 2013) under water stress condition. Among parents, the variation was between 9.54 (Galaxy 2013) to 14.22 (B 215 B 1103) for tillers plant ${ }^{-1}$ under normal condition while mean values ranged from 6.10 (B 215 B 1103) to 10.71 (ESYWT P 117) for this character under water stress condition. Similarly, under normal condition among crosses, this range varied from 8.14 (ESYWT P $117 \times$ Lasani 2008 ) to 15.43 (B 215 B $1103 \times$ Galaxy 2013) whereas under water stress condition, the mean performance for crosses varied from 5.14 (ESYWT P $117 \times 2511$ ) to 12.02 (B 215 B $1103 \times$ Galaxy 2013). For spike length among parents under normal condition, the mean values were between $8.10 \mathrm{~cm}$ (2511) to $10.17 \mathrm{~cm}$ (B $215 \mathrm{~B} 1103$ ) while mean performance ranged from $6.75 \mathrm{~cm}$ (2511) to $8.95 \mathrm{~cm}$ (B $215 \mathrm{~B} 1103$ ) under water stress condition. Among crosses, the mean values ranged from $7.73 \mathrm{~cm}$ (GA $2002 \times x$ Galaxy 2013) to $10.28 \mathrm{~cm}$ (B 215 B $1103 \times$ Galaxy 2013) under normal condition whereas this mean value range in crosses under water stress condition was found between $7.04 \mathrm{~cm}$ (ESYWT P $117 \times$ Galaxy 2013) to $9.36 \mathrm{~cm}$ (B 215 B $1103 \times$ Galaxy 2013). For grains spike ${ }^{-1}$ among parents under normal condition, the mean performance was observed between 49.70 (Galaxy 2013) to 65.27 (B 215 B 1103) while mean performance values ranged from 33.60 (Galaxy 2013) to 46.57 (B 215 B 
1103) for this trait under water stress condition. Likewise, among crosses under normal condition, the mean value varied from 48.59 (BARS $2009 \times 2511$ ) to $68.13(\mathrm{~B}$ 215 B $1103 \times$ Galaxy 2013). The mean performance range in crosses under water stress condition for this character was found from 33.05 (BARS $2009 \times 2511$ ) to 47.40 (B 215 B $1103 \times$ Galaxy 2013). Among parents, the mean values were between 49.00 (Galaxy 2013) to 54.48 (B 215 B 1103) under normal condition while mean performance ranged from 33.51 (Galaxy 2013) to 41.07 (B 215 B 1103) under water stress condition for 1000-grain weight. Among crosses, the mean values ranged from 49.70 (Chakwal $86 \times 2511$ ) to 56.53 (B 215 B $1103 \times$ Galaxy 2013) for this trait under normal condition while under water stress condition the mean values range in crosses was found between 33.99 (Chakwal $86 \times 2511$ ) to 42.90 (B 215 B $1103 \times$ Galaxy 2013). The mean performance range among parents varied between 50.74 (Galaxy 2013) to 68.39 (B 215 B 1103) for biological yield plant ${ }^{-1}$ under normal conditions while mean values ranged from 40.10 (2511) to 52.69 (Chakwal 86) under water stress condition. Among crosses, the range varied from 53.03 (Chakwal $50 \times$ Lasani 2008) to 70.84 (B 215 B $1103 \times$ Galaxy 20131) under normal condition whereas this mean performance under water stress condition ranged from 38.31 (Chakwal $50 \times$ Lasani 2008) to 53.40 (B 215 B $1103 \times$ Galaxy 2013). Under normal condition, for grain yield plant ${ }^{-1}$ among parents, the mean performance was found between 22.73 (Galaxy 2013) to 32.50 (B 215 B 1103) whereas this mean performance values ranged from 17.05 (Galaxy 2013) to 23.23 (B 215 B 1103) for this character under water stress condition. Similarly, among crosses, the mean values varied from 22.20 (B 215 B $1103 \times$ Lasani 2008) to 35.55 (B 215 B $1103 \times$ Galaxy 2013) under normal condition. Likewise, this mean performance range in crosses under water stress conditions was found from 16.73 (B 215 B $1103 \times$ Lasani 2008) to 25.71 (B 215 B $1103 \times$ Galaxy 2013).

\section{Estimation of general combining ability (GCA)}

Combining ability is an assessment of the value of parents on the basis of performance of their progenies by using a specific breeding approach. When crosses are more productive, they are supposed to have good combining ability. GCA effects of lines and testers for evaluated traits are reflected in Table 4a-d. The plant height with negative values of GCA effects is considered favorable as short stature plants are considered good due to their ability to withstand lodging (Muneer et al., 2016). Among lines under normal condition, Chakwal 86 and BARS 2009 were observed as good combiners having GCA values of (- 4.87) and (- 8.89), respectively whereas under water stress condition, lines BARS 2009 (-6.67), Chakwal 50 (-0.61) and ESWYT P 117 (-1.40) were good general combiners. Similarly, among testers under normal condition, Galaxy 2013 and 2511 were observed good combiner having GCA values of $(-1.31)$ and $(-1.10)$, respectively whereas under water stress condition, testers Galaxy 2013 (-0.97) and Lasani 2008 (-0.94) were found good general combiners. These results are in accordance with the findings of Muneer et al. (2016). Negative GCA effects for flag leaf area are favorable due to less transpirational loss. Lines BARS 2009, GA 2002 and ESWYT P 117, under both conditions, reflected negative and significant results while testers Lasani 2008 under normal condition and 2511 and Lasani 2008 under water stress condition were good general combiners. Tillers plant-1 is a yield associated character and plants with higher number of fertile tillers result in more grain yield. Under both condition, lines BARS 2009, Chakwal 86 
and Chakwal 50 exhibited positive and significant GCA effects with values 1.02, 0.58 and 0.83 for normal and $0.94,0.35$ and 0.53 under water stress condition, respectively. For testers, Galaxy 2013 was a good general combiner under both conditions. The findings of Majeed et al., (2011), Muneer et al. (2016), Saeed et al. (2016) and Iqbal et al. (2007) are also supportive to these findings. Spikes with greater length are desirable because of more spikelets per spike resulting in greater grain yield. Under normal condition, line B 215 B 1103 and under water stress condition, lines BARS 2009 and B 215 B 1103 were positive and significant general combiners. Grains spike-1 is a significant attribute contributing to overall grain yield and hence positive and significant GCA effects are desirable owing to yield per spike. Under both conditions among lines, GA 2002, ESWYT P 117 and B 215 B 1103 reflected positive and significant combining ability results. Among testers, Lasani 2008 was a good general combiner under both conditions. Muneer et al. (2016) and Iqbal et al. (2007) also witnessed the same results. Thousand-grain weight is a significant yield related trait and could be practiced as a selection criterion for high production in wheat. Among lines, B 215 B 1103 under both conditions showed maximum desirable GCA effects and thus proved to be good general combiners for this particular trait. However, testers Galaxy 2013 and Lasani 2008 under water stress condition reflected significant and positive GCA effects. For lines, biological yield plant-1, was positive and significant for Chakwal 86, ESWYT P 117 and B 215 B 1103 under both conditions whereas for testers, it proved to be positive and significant for Galaxy 2013 and 2511 under both conditions. Grain yield being a complex character, the plant breeders are particularly interested in developing high yielding varieties to cope with food demand of the masses by improving directly or indirectly this trait. Line Chakwal 86 demonstrated as a best general combiner under both conditions whereas the tester Galaxy 2013 reflected significant and positive GCA effects under both environmental conditions. These findings are in line with the results of Muneer et al. (2016), Sattar et al. (2018) and Jatav et al. (2014). It is suggested that line Chakwal 86 having high GCA for tillers plant-1, biological yield plant-1 and grain yield plant-1 under both conditions and tester Galaxy 2013 having good GCA for plant height, tillers plant-1, biological yield plant-1 and grain yield plant-1 under both environmental conditions can be easily employed for exploring high yielding wheat varieties in future.

Table 4a. GCA effects of lines and testers under normal and water stress conditions

\begin{tabular}{c|c|c|c|c}
\hline \multirow{2}{*}{ Genotypes } & \multicolumn{2}{|c|}{ Plant height } & \multicolumn{2}{c}{ Flag leaf area } \\
\cline { 2 - 5 } & Normal & Water stress & Normal & Water stress \\
\hline Chakwal 86 & $-4.87^{* *}$ & $3.03^{* *}$ & -0.01 & -0.16 \\
BARS 2009 & $-8.89^{* *}$ & $-6.67 * *$ & $-0.97^{* *}$ & $-0.73^{* *}$ \\
Chakwal 50 & $0.95^{* *}$ & $-0.61^{* *}$ & $2.11^{* *}$ & $2.26^{* *}$ \\
GA 2002 & $9.07^{* *}$ & 3.74 & $-0.95^{* *}$ & $-0.72^{* *}$ \\
ESWYT P 117 & $1.45^{* *}$ & $-1.40^{* *}$ & $-2.14^{* *}$ & $-2.08^{* *}$ \\
B 215 B 1103 & $2.30^{* *}$ & $1.92^{* *}$ & $1.96^{* *}$ & $1.43^{* *}$ \\
Galaxy 2013 & $-1.31^{* *}$ & $-1.07^{* *}$ & $1.41^{* *}$ & $1.36^{* *}$ \\
2511 & $-1.10^{* *}$ & $2.01^{* *}$ & -0.26 & $-0.58^{* *}$ \\
Lasani 2008 & $2.41^{* *}$ & $-0.94 * *$ & $-1.15^{* *}$ & $-0.78^{* *}$ \\
\hline
\end{tabular}


Table $4 \boldsymbol{b}$. GCA effects of lines and testers under normal and water stress conditions

\begin{tabular}{c|c|c|c|c}
\hline \multirow{2}{*}{ Genotypes } & \multicolumn{2}{|c|}{ Tillers plant $^{-1}$} & \multicolumn{2}{c}{ Spike length } \\
\cline { 2 - 5 } & Normal & Water stress & Normal & Water stress \\
\hline Chakwal 86 & $1.02^{* *}$ & $0.94 * *$ & 0.24 & 0.07 \\
BARS 2009 & $0.58^{* *}$ & $0.35^{* *}$ & 0.20 & $0.26^{* *}$ \\
Chakwal 50 & $0.83^{* *}$ & $0.53^{* *}$ & -0.21 & $-0.29 * *$ \\
GA 2002 & -0.32 & $-0.35^{* *}$ & $-0.64 * *$ & $-0.43^{* *}$ \\
ESWYT P 117 & $-1.77^{* *}$ & $-1.678^{* *}$ & -0.03 & -0.11 \\
B 215 B 1103 & -0.34 & 0.20 & $0.44 * *$ & $0.51^{* *}$ \\
Galaxy 2013 & $1.12^{* *}$ & $0.83 * *$ & 0.05 & 0.09 \\
2511 & -0.25 & $-0.80^{* *}$ & -0.05 & -0.08 \\
Lasani 2008 & $-0.87 * *$ & -0.30 & -0.01 & -0.01 \\
\hline
\end{tabular}

Table 4c. GCA effects of lines and testers under normal and water stress conditions

\begin{tabular}{c|c|c|c|c}
\hline \multirow{2}{*}{ Genotypes } & \multicolumn{2}{|c|}{ Grains spike } & \multicolumn{2}{c}{ 1000-grain weight } \\
\cline { 2 - 5 } & Normal & Water stress & Normal & Water stress \\
\hline Chakwal 86 & $-5.36^{* *}$ & $-4.06^{* *}$ & -1.04 & $-0.55^{* *}$ \\
BARS 2009 & $-7.79^{* *}$ & $-6.15^{* *}$ & -1.01 & $-0.94^{* *}$ \\
Chakwal 50 & $-7.57^{* *}$ & $-5.92^{* *}$ & -0.78 & -0.27 \\
GA 2002 & $5.62^{* *}$ & $4.64 * *$ & -0.35 & $-0.56^{* *}$ \\
ESWYT P 117 & $6.88^{* *}$ & $5.15^{* *}$ & 0.86 & $-0.54 * *$ \\
B 215 B 1103 & $8.22^{* *}$ & $6.35^{* *}$ & $2.32^{* *}$ & $2.86^{* *}$ \\
Galaxy 2013 & 0.16 & -0.17 & 0.56 & $0.69^{* *}$ \\
2511 & $-0.94 * *$ & $-0.62^{* *}$ & $-1.15 * *$ & $-1.23 * *$ \\
Lasani 2008 & $0.78^{* *}$ & $0.79 * *$ & 0.60 & $0.54 * *$ \\
\hline
\end{tabular}

Table 4d. GCA effects of lines and testers under normal and water stress conditions

\begin{tabular}{c|c|c|c|c}
\hline \multirow{2}{*}{ Genotypes } & \multicolumn{2}{|c|}{ Biological yield plant ${ }^{\mathbf{1}}$} & \multicolumn{2}{c}{ Grain yield plant $^{\mathbf{1}}$} \\
\cline { 2 - 5 } & Normal & Water stress & Normal & Water stress $^{*}$ \\
\hline Chakwal 86 & $2.45^{* *}$ & $2.44^{* *}$ & $1.97^{* *}$ & $1.57^{* *}$ \\
BARS 2009 & $-3.26^{* *}$ & $-1.19^{* *}$ & $-2.36^{* *}$ & $-1.09^{* *}$ \\
Chakwal 50 & $-7.85^{* *}$ & $-6.02^{* *}$ & -0.66 & $-0.53^{* *}$ \\
GA 2002 & 0.55 & -0.67 & 0.14 & -0.24 \\
ESWYT P 117 & $4.94^{* *}$ & $4.34^{* *}$ & 0.80 & -0.06 \\
B 215 B 1103 & $3.17^{* *}$ & $1.11^{* *}$ & 0.11 & 0.35 \\
Galaxy 2013 & $2.16^{* *}$ & $1.54^{* *}$ & $0.98^{* *}$ & $0.72^{* *}$ \\
2511 & $0.76^{* *}$ & $0.98^{* *}$ & -0.33 & -0.07 \\
Lasani 2008 & $-2.92^{* *}$ & $-2.51^{* *}$ & -0.65 & $-0.65^{* *}$ \\
\hline
\end{tabular}

Estimation of specific combining ability (SCA)

SCA results of crosses are reflected in Table 5a-d. Crosses Chakwal $86 \times$ Lasani 2008, Chakwal $50 \times$ Galaxy 2013, GA $2002 \times$ Lasani 2008, ESWYT P $117 \times$ Lasani 
2008 and B 215 B $1103 \times$ Galaxy 2013 exhibited positive and significant SCA effects for plant height under both conditions. Crosses Chakwal $86 \times$ Galaxy 2013, BARS 2009 $\times 2511$, GA $2002 \times$ Galaxy 2013, ESWYT P $117 \times 2511$, ESWYT P $117 \times$ Lasani 2008 and B 215 B $1103 \times$ Lasani 2008 were best specific combiners under normal condition environment whereas for water stress condition, best combiners were Chakwal $86 \times$ Galaxy 2013, GA $2002 \times$ Galaxy 2013, ESWYT P $117 \times 2511$ and B 215 B $1103 \times$ Lasani 2008 for flag leaf area. The same findings were reported by Srivastava et al. (2012), Singh and Kumar (2014) and Sattar et al. (2018). Under normal condition, crosses like Chakwal $86 \times$ Lasani 2008, Chakwal $50 \times$ Lasani 2008, GA $2002 \times 2511$, ESWYT P $117 \times 2511$ and B 215 B $1103 \times$ Galaxy 2013 displayed significant and favorable SCA effects and proved to be good combiners for tillers plant ${ }^{-1}$. Likewise, under water stress condition, for tillers plant ${ }^{-1}$, the crosses Chakwal $86 \times 2511$, BARS $2009 \times$ Lasani 2008, Chakwal $50 \times 2511$ and B 215 B $1103 \times$ Galaxy 2013 proved to be good specific combiners. Jain and Sastry (2012), Hammad et al. (2013), Singh and Kumar (2014), Muneer et al. (2016), and Kumar et al. (2018) also reported similar results in their experiments for tillers plant ${ }^{-1}$. Two crosses ESWYT P $117 \times$ Lasani 2008 and B 215 B $1103 \times$ Galaxy 2013 under normal condition and three crosses GA $2002 \times$ 2511, ESWYT P $117 \times$ Lasani 2008 and B 215 B $1103 \times$ Galaxy 2013 under water stress condition had significantly positive SCA effects for spike length. For grains spike ${ }^{-}$ ${ }^{1}$, all cross combinations under both conditions showed non-significant results except GA $2002 \times 2511$. Similar results were shown by Shabbir et al. (2012) and Bibi et al. (2013) for this trait. Positive and favorable SCA effects for 1000 grain weight were witnessed for six crosses like Chakwal $86 \times$ Lasani 2008, Chakwal $50 \times$ Lasani 2008, GA $2002 \times$ Lasani 2008, ESWYT P $117 \times$ Galaxy 2013, B 215 B $1103 \times$ Galaxy 2013 and B 215 B $1103 \times 2511$ under water stress condition while no cross had significantly positive SCA effects under normal condition. Out of these six crosses under water stress condition, the best three in order of merit were Chakwal $86 \times$ Lasani 2008, Chakwal 50 $\times$ Lasani 2008 and B 215 B $1103 \times 2511$. Similar findings were given by Ahmad et al. (2011), Majeed et al. (2011), Hammad et al. (2013) and Muneer et al. (2016). Under both conditions, six cross combinations Chakwal $86 \times$ Galaxy 2013, BARS $2009 \times$ Galaxy 2013, Chakwal $50 \times$ Lasani 2008, GA $2002 \times$ Lasani 2008, ESWYT P $117 \times$ Lasani 2008 and B 215 B $1103 \times$ Galaxy 2013 reflected positive and significant SCA effects for biological yield plant ${ }^{-1}$. However, B 215 B $1103 \times$ Galaxy 2013 and Chakwal $86 \times$ Galaxy 2013 were the best combiners. Crosses with desired and significant SCA effects under normal condition for grain yield plant ${ }^{-1}$ were GA $2002 \times 2511$ and B 215 B $1103 \times$ Galaxy whereas under water stress condition, the positive and significant results were obtained for Chakwal $86 \times$ Lasani 2008, GA $2002 \times 2511$, ESWYT P 117 $\times 2511$ and B 215 B $1103 \times$ Galaxy 2013. Similarly, under both conditions, the best combiners were GA $2002 \times 2511$ and B 215 B $1103 \times$ Galaxy 2013 for grain yield plant $^{-1}$. These results are in confirmation with Majeed et al. (2011), Bibi et al. (2013), Fellahi et al. (2013), Muneer et al. (2016) and Sattar et al. (2018).

\section{Heritability}

Genotypic variance (Vg), Phenotypic variance (Vp), Environmental variance (Ve) and Heritability $\left(\mathrm{H}^{2}\right)$ estimates for studied traits evaluated under both environmental conditions are presented in Table 8. The characters like plant height, flag leaf area, tillers plant ${ }^{-1}$, grains spike ${ }^{-1}$ and biological yield plant ${ }^{-1}$ under both environments showed high heritability. However, under water stress environments, all traits reflected 
moderate to high heritability. Similarly, spike length, 1000-grain weight and grain yield plant $^{-1}$ reflected medium to high heritability.

Table 5a. SCA effects of crosses under normal and water stress conditions

\begin{tabular}{c|c|c|c|c}
\hline \multirow{2}{*}{ Crosses } & \multicolumn{2}{|c|}{ Plant height } & \multicolumn{2}{c}{ Flag leaf area } \\
\cline { 2 - 5 } & Normal & Water stress & Normal & Water stress \\
\hline Chakwal 86 x Galaxy 2013 & $2.31^{* *}$ & $3.70^{* *}$ & $-3.77^{* *}$ & $-3.00^{* *}$ \\
Chakwal 86 x 2511 & -0.38 & 0.76 & -0.35 & -0.21 \\
Chakwal 86 x Lasani 2008 & $-1.93^{* *}$ & $-4.46^{* *}$ & $4.12^{* *}$ & $3.21^{* *}$ \\
BARS 2009 x Galaxy 2013 & 0.75 & -0.06 & 0.10 & -0.07 \\
BARS 2009 x 2511 & $-2.45^{* *}$ & -1.36 & $-1.13^{* *}$ & -0.49 \\
BARS 2009 x Lasani 2008 & $1.70^{* *}$ & 1.43 & $1.03^{* *}$ & 0.56 \\
Chakwal 50 x Galaxy 2013 & $-6.38^{* *}$ & $-5.69^{* *}$ & 0.08 & -0.51 \\
Chakwal 50 x 2511 & -0.26 & $-2.45^{* *}$ & 0.86 & 0.58 \\
Chakwal 50 x Lasani 2008 & $6.64^{* *}$ & $8.14^{* *}$ & -0.94 & -0.07 \\
GA 2002 x Galaxy 2013 & $3.52^{* *}$ & $3.86^{* *}$ & $-1.13^{* *}$ & $-2.66^{* *}$ \\
GA 2002 x 2511 & 0.39 & -0.05 & -0.09 & -0.32 \\
GA 2002 x Lasani 2008 & $-3.91^{* *}$ & $-3.81^{* *}$ & $1.22^{* *}$ & $2.97 * *$ \\
ESWYT P 117 x Galaxy 2013 & $5.54^{* *}$ & 1.82 & $3.08^{* *}$ & $2.32^{* *}$ \\
ESWYT P 117 x 2511 & -0.97 & 0.36 & $-1.64^{* *}$ & $-1.69^{* *}$ \\
ESWYT P 117 x Lasani 2008 & $-4.57^{* *}$ & $-2.18^{* *}$ & $-1.44^{* *}$ & -0.64 \\
B 215 B 1103 x Galaxy 2013 & $-5.74^{* *}$ & $-3.63^{* *}$ & $1.65^{* *}$ & $3.91^{* *}$ \\
B 215 B 1103 x 2511 & $3.66^{* *}$ & $2.74^{* *}$ & $2.35^{* *}$ & $2.12^{* *}$ \\
B 215 B 1103 x Lasani 2008 & $2.08^{* *}$ & 0.89 & $-4.00^{* *}$ & $-6.03^{* *}$ \\
\hline
\end{tabular}

Table 5b. SCA effects of crosses under normal and water stress conditions

\begin{tabular}{c|c|c|c|c}
\hline \multirow{2}{*}{ Crosses } & \multicolumn{2}{|c|}{ Tillers plant $^{-1}$} & \multicolumn{2}{c}{ Spike length } \\
\cline { 2 - 5 } & Normal & Water stress & Normal & Water stress \\
\hline Chakwal 86 x Galaxy 2013 & -0.61 & $-1.30^{* *}$ & 0.14 & 0.01 \\
Chakwal 86 x 2511 & $-0.99^{* *}$ & $1.24^{* *}$ & -0.04 & 0.13 \\
Chakwal 86 x Lasani 2008 & $1.60^{* *}$ & 0.06 & -0.09 & -0.14 \\
BARS 2009 x Galaxy 2013 & -0.65 & 0.50 & -0.33 & -0.22 \\
BARS 2009 x 2511 & 0.37 & -0.16 & 0.36 & 0.24 \\
BARS 2009 x Lasani 2008 & 0.27 & $0.66^{* *}$ & -0.03 & -0.03 \\
Chakwal 50 x Galaxy 2013 & $-0.88^{* *}$ & $-1.27^{* *}$ & 0.06 & 0.04 \\
Chakwal 50 x 2511 & -0.52 & $1.44^{* *}$ & 0.19 & 0.14 \\
Chakwal 50 x Lasani 2008 & $1.40^{* *}$ & -0.17 & -0.25 & -0.18 \\
GA 2002 x Galaxy 2013 & -0.39 & 0.12 & -0.32 & -0.29 \\
GA 2002 x 2511 & $0.88^{* *}$ & -0.15 & 0.46 & $0.34 * *$ \\
GA 2002 x Lasani 2008 & -0.49 & 0.02 & -0.14 & -0.05 \\
ESWYT P 117 x Galaxy 2013 & 0.06 & 0.37 & $-0.71 * *$ & $-0.62^{* *}$ \\
ESWYT P 117 x 2511 & $1.34^{* *}$ & $-0.82^{* *}$ & -0.11 & -0.27 \\
ESWYT P 117 x Lasani 2008 & $-1.40^{* *}$ & 0.44 & $0.82^{* *}$ & $0.89^{* *}$ \\
B 215 B 1103 x Galaxy 2013 & $2.47^{* *}$ & $2.57^{* *}$ & $1.16^{* *}$ & $1.08^{* *}$ \\
B 215 B 1103 x 2511 & $-1.09^{* *}$ & $-1.56^{* *}$ & $-0.85^{* *}$ & $-0.58^{* *}$ \\
B 215 B 1103 x Lasani 2008 & $-1.38^{* *}$ & $-1.01^{* *}$ & -0.31 & $-0.49^{* *}$ \\
\hline
\end{tabular}


Table 5c. SCA effects of crosses under normal and water stress conditions

\begin{tabular}{c|c|c|c|c}
\hline \multirow{2}{*}{ Crosses } & \multicolumn{2}{|c|}{ Grains spike $^{-1}$} & \multicolumn{2}{c}{ 1000-grain weight } \\
\cline { 2 - 5 } & Normal & Water stress & Normal & Water stress \\
\hline Chakwal 86 x Galaxy 2013 & 0.68 & 0.61 & -0.76 & $-0.92^{* *}$ \\
Chakwal 86 x 2511 & -1.31 & -0.86 & -1.05 & $-1.73^{* *}$ \\
Chakwal 86 x Lasani 2008 & 0.62 & 0.25 & 1.81 & $2.65^{* *}$ \\
BARS 2009 x Galaxy 2013 & 0.90 & -0.45 & -0.12 & -0.09 \\
BARS 2009 x 2511 & -1.32 & -0.32 & -0.41 & 0.01 \\
BARS 2009 x Lasani 2008 & 0.42 & 0.77 & 0.53 & 0.09 \\
Chakwal 50 x Galaxy 2013 & 0.12 & 0.50 & -0.68 & $-1.00^{* *}$ \\
Chakwal 50 x 2511 & 0.07 & -0.09 & -0.64 & $-1.32^{* *}$ \\
Chakwal 50 x Lasani 2008 & -0.19 & -0.41 & 1.32 & $2.32^{* *}$ \\
GA 2002 x Galaxy 2013 & $-1.79 * *$ & -1.09 & -0.78 & $-1.49^{* *}$ \\
GA 2002 x 2511 & $1.66^{* *}$ & $1.22^{* *}$ & -0.41 & 0.57 \\
GA 2002 x Lasani 2008 & 0.14 & -0.13 & 1.18 & $0.93^{* *}$ \\
ESWYT P 117 x Galaxy 2013 & -1.02 & -0.65 & 1.63 & $1.67^{* *}$ \\
ESWYT P 117 x 2511 & 0.76 & 0.04 & 1.06 & 0.41 \\
ESWYT P 117 x Lasani 2008 & 0.25 & 0.62 & $-2.69 * *$ & $-2.07 * *$ \\
B 215 B 1103 x Galaxy 2013 & 1.10 & 1.08 & 0.71 & $1.84^{* *}$ \\
B 215 B 1103 x 2511 & 0.14 & 0.01 & 1.45 & $2.07^{* *}$ \\
B 215 B 1103 x Lasani 2008 & -1.24 & -1.09 & -2.16 & $-3.91 * *$ \\
\hline
\end{tabular}

Table 5d. SCA effects of crosses under normal and water stress conditions

\begin{tabular}{c|c|c|c|c}
\hline \multirow{2}{*}{ Crosses } & \multicolumn{2}{|c|}{ Biological yield plant } & \multicolumn{2}{c}{ Grain yield plant $^{-1}$} \\
\cline { 2 - 5 } & Normal & Water stress & Normal & Water stress \\
\hline Chakwal 86 x Galaxy 2013 & $2.73^{* *}$ & $1.67^{* *}$ & $-1.74^{* *}$ & $-1.59^{* *}$ \\
Chakwal 86 x 2511 & $-1.61^{* *}$ & -1.17 & 0.13 & 0.33 \\
Chakwal 86 x Lasani 2008 & -1.11 & -0.50 & 1.61 & $1.25^{* *}$ \\
BARS 2009 x Galaxy 2013 & $2.06^{* *}$ & $2.80^{* *}$ & 0.05 & 0.37 \\
BARS 2009 x 2511 & 0.56 & -1.06 & -0.87 & $-1.07^{* *}$ \\
BARS 2009 x Lasani 2008 & $-2.62^{* *}$ & $-1.74^{* *}$ & 0.82 & 0.69 \\
Chakwal 50 x Galaxy 2013 & $-1.75^{* *}$ & -0.54 & -1.43 & -0.21 \\
Chakwal 50 x 2511 & 0.21 & 0.38 & -0.15 & -0.66 \\
Chakwal 50 x Lasani 2008 & $1.53^{* *}$ & 0.16 & 1.58 & 0.87 \\
GA 2002 x Galaxy 2013 & $-3.72^{* *}$ & $-5.87^{* *}$ & $-2.04^{* *}$ & $-1.08^{* *}$ \\
GA 2002 x 2511 & 1.02 & 0.80 & $1.72^{* *}$ & $1.19^{* *}$ \\
GA 2002 x Lasani 2008 & $2.70^{* *}$ & $5.06^{* *}$ & 0.32 & -0.10 \\
ESWYT P 117 x Galaxy 2013 & $-2.56^{* *}$ & $-2.12^{* *}$ & $-1.73^{* *}$ & $-1.69^{* *}$ \\
ESWYT P 117 x 2511 & 0.09 & -0.92 & 1.24 & $0.99^{* *}$ \\
ESWYT P 117 x Lasani 2008 & $2.47^{* *}$ & $3.05^{* *}$ & 0.49 & 0.71 \\
B 215 B 1103 x Galaxy 2013 & $3.24^{* *}$ & $4.06^{* *}$ & $6.90^{* *}$ & $4.20^{* *}$ \\
B 215 B 1103 x 2511 & -0.26 & $1.97^{* *}$ & $-2.08^{* *}$ & -0.78 \\
B 215 B 1103 x Lasani 2008 & $-2.98^{* *}$ & $-6.03^{* *}$ & $-4.82^{* *}$ & $-3.42^{* *}$ \\
\hline
\end{tabular}




\section{Component of variance and proportional contribution of parents and crosses}

Genetic component of variance i.e. variance due to GCA $\left(\sigma^{2} \mathrm{~g}\right)$ and variance due to SCA $\left(\sigma^{2} s\right)$ were worked out from analysis of variance for combining ability under both conditions and are presented in Table 6 . The ratio between $\sigma^{2} \mathrm{~g} / \sigma^{2} \mathrm{~s}$ was calculated to determine the relative role of gene action. The ratio between $\sigma^{2} \mathrm{~g} / \sigma^{2} \mathrm{~s}$ greater than 1 reflected additive type of gene action and the ratio less than one indicated nonadditive (dominance) type of gene action. Variance due to GCA greater than SCA variance showed additive types of gene action but variance due to SCA greater than GCA variance indicated non-additive type of gene action. Variance due to GCA equal to the SCA variance reflected the epistasis (non-allelic interaction).

In the present studies, the estimated values of genetic components of variance due to $\sigma^{2} \mathrm{~g}$ and $\sigma^{2} \mathrm{~s}$ revealed the predominance of SCA indicating the role of non-additive (dominance) type of gene action in the expression of characters in both conditions except grains spike ${ }^{-1}$ which shows the additive type of gene action under both conditions. Dominance and additive type of gene actions were studied for various yield related traits under normal and water stress conditions. Non-additive gene action for plant height, flag leaf area, tillers per plant ${ }^{-1}$, spike length, 1000-grain weight, biological yield plant ${ }^{-1}$ and grain yield plant ${ }^{-1}$ was observed. These results are in accordance with Srivastava et al. (2012) and Sattar et al. (2018) who observed nonadditive type of gene action for plant height, flag leaf area, tillers plant ${ }^{-1}, 1000$-grain weight and grain yield plant ${ }^{-1}$. Additive type of gene action for spike length and grain weight per spike has been reported earlier by Ahmad et al. (2011) and Hammad et al. (2013).

Proportional contribution of lines, testers and line $\times$ tester interaction to the total variance for different plant characters is presented in Table 7 . While observing the proportional contribution of lines, testers and their hybrids to the total variance of eight studied traits, lines were more prominent for the characters like plant height, grains spike ${ }^{-1}$ and biological yield plant ${ }^{-1}$ under both conditions. The contribution of testers was very low in proportion in most of the studied traits under both conditions. Line $\times$ tester interaction contributed predominantly to flag leaf area, tillers plant ${ }^{-1}$, spike length, 1000-grain weight and grain yield plant ${ }^{-1}$ under both conditions. Similar findings were reported by Shabbir et al. (2012) and Fellahi et al. (2013) and Sattar et al. (2018).

Table 6. Variances due to GCA, SCA under normal and water stress conditions

\begin{tabular}{|c|c|c|c|c|c|c|}
\hline \multirow{2}{*}{ Traits } & \multicolumn{2}{|c|}{$\tilde{\sigma}^{2}$ GCA } & \multicolumn{2}{|c|}{$\sigma^{2} \mathrm{SCA}$} & \multicolumn{2}{|c|}{$\tilde{\sigma}^{2}$ GCA/ $\tilde{\sigma}^{2} \mathrm{SCA}$} \\
\hline & $\mathbf{N}$ & WS & $\mathbf{N}$ & WS & $\mathbf{N}$ & WS \\
\hline Plant height & 2.477 & 0.617 & 22.914 & 19.202 & 0.108 & 0.032 \\
\hline Flag leaf area & 0.058 & -0.087 & 7.399 & 9.891 & 0.008 & -0.009 \\
\hline Tillers plant $^{-1}$ & 0.072 & 0.040 & 2.061 & 1.788 & 0.035 & 0.023 \\
\hline Spike length & -0.003 & -0.002 & 0.322 & 0.316 & -0.009 & -0.007 \\
\hline Grains spike ${ }^{-1}$ & 4.644 & 2.823 & 0.986 & 0.534 & 4.712 & 5.283 \\
\hline 1000-grain weight & 0.100 & 0.038 & 1.256 & 5.122 & 0.080 & 0.007 \\
\hline Biological yield plant ${ }^{-1}$ & 1.925 & 0.773 & 7.669 & 14.523 & 0.251 & 0.053 \\
\hline Grain yield plant ${ }^{-1}$ & -0.151 & -0.068 & 9.185 & 4.206 & -0.016 & -0.016 \\
\hline
\end{tabular}

$\mathrm{N}=$ normal, $\mathrm{WS}=$ water stress, $\mathrm{L} \times \mathrm{T}=$ line $\times$ tester 
Table 7. Gene action, contribution of parents and their crosses under normal and water stress conditions

\begin{tabular}{|c|c|c|c|c|c|c|c|c|c|c|}
\hline \multirow{3}{*}{ Traits } & \multicolumn{4}{|c|}{ Gene action } & \multicolumn{6}{|c|}{ Contribution of parents and their crosses } \\
\hline & \multicolumn{2}{|c|}{ Additive } & \multicolumn{2}{|c|}{ Dominance } & \multicolumn{2}{|c|}{ Line } & \multicolumn{2}{|c|}{ Tester } & \multicolumn{2}{|c|}{$L \times T$} \\
\hline & $\mathbf{N}$ & WS & $\mathbf{N}$ & WS & $\mathbf{N}$ & WS & $\mathbf{N}$ & WS & $\mathbf{N}$ & WS \\
\hline $\mathrm{P}$ & .95 & 23 & .91 & 19.20 & 66.91 & 48.16 & 6.04 & 7.94 & 27.05 & 43.90 \\
\hline Flag & 0.12 & -0.17 & 7.40 & 9.89 & 31.33 & 24.23 & 14.40 & 10.77 & 54.26 & 65.00 \\
\hline Tillers 1 & 0.14 & 0.08 & 2.06 & 1.79 & 32.16 & 32.37 & 24.80 & 20.13 & 43.04 & 47.50 \\
\hline Spike le & -0.01 & -0.005 & 0.32 & 0.32 & 35.54 & 34.59 & 0.50 & 1.72 & 63.96 & 63.69 \\
\hline Grains spike $^{-1}$ & 9.29 & 5.65 & 0.99 & 0.53 & 97.25 & 97.33 & 1.01 & 1.15 & 1.74 & 1.53 \\
\hline 1000-grain wt. & 0.20 & 0.08 & 1.26 & 5.12 & 39.95 & 31.24 & 17.78 & 14.28 & 42.27 & 54.49 \\
\hline Biological yield plant ${ }^{-1}$ & 3.85 & 1.55 & 7.67 & 14.52 & 67.23 & 48.23 & 16.41 & 14.48 & 16.35 & 37.29 \\
\hline Grain yield plant ${ }^{-1}$ & -0.30 & -0.14 & 9.18 & 4.21 & 22.72 & 19.88 & 6.45 & 9.16 & 70.83 & 70.96 \\
\hline
\end{tabular}

Table 8. Genotypic variance (Vg), phenotypic variance (Vp), environmental variance (Ve) and heritability $\left(\mathrm{H}^{2}\right)$ estimates for studied traits evaluated under normal and water stress conditions

\begin{tabular}{|c|c|c|c|c|c|c|c|c|}
\hline \multirow{2}{*}{ Traits } & \multicolumn{2}{|c|}{$\begin{array}{c}\text { Environmental } \\
\text { variance }\end{array}$} & \multicolumn{2}{|c|}{$\begin{array}{l}\text { Genotypic } \\
\text { variance }\end{array}$} & \multicolumn{2}{|c|}{$\begin{array}{c}\text { Phenotypic } \\
\text { variance }\end{array}$} & \multicolumn{2}{|c|}{ Heritability (b.s) } \\
\hline & $\mathbf{N}$ & WS & $\mathbf{N}$ & WS & $\mathbf{N}$ & WS & $\mathbf{N}$ & WS \\
\hline Plant height & 1.60 & 2.91 & 43.82 & 22.99 & 45.42 & 25.90 & 96.48 & 88.78 \\
\hline Flag leaf area & 0.75 & 0.71 & 9.33 & 9.57 & 10.08 & 10.28 & 92.52 & 93.05 \\
\hline Tillers plant $^{-1}$ & 0.33 & 0.26 & 2.62 & 2.08 & 2.95 & 2.34 & 88.91 & 88.78 \\
\hline Spike length & 0.12 & 0.19 & 0.33 & 0.36 & 0.45 & 0.55 & 73.33 & 65.45 \\
\hline Grains spike $^{-1}$ & 1.78 & 0.90 & 42.22 & 25.63 & 44.00 & 26.53 & 95.95 & 96.59 \\
\hline 1000-grain weight & 0.68 & 1.11 & 3.38 & 1.88 & 4.06 & 2.99 & 83.25 & 62.87 \\
\hline Biological yield plant ${ }^{-1}$ & 1.72 & 1.08 & 35.27 & 22.61 & 36.99 & 23.69 & 95.35 & 95.43 \\
\hline Grain yield plant ${ }^{-1}$ & 2.08 & 2.06 & 8.31 & 8.32 & 10.39 & 10.38 & 80.07 & 80.15 \\
\hline
\end{tabular}

\section{Conclusion}

The parent Chakwal 86 and Galaxy 2013 possessed highest general combining ability for number of tillers plant ${ }^{-1}$, biological yield plant ${ }^{-1}$ and grain yield plant $^{-1}$ under both environments. Crosses B 215 B $1103 \times$ Galaxy 2013, GA $2002 \times 2511$ and ESWYT P $117 \times$ Lasani 2008 were the ideal specific combiners for flag leaf area, tillers plant ${ }^{-1}$, spike length, and biological yield plant ${ }^{-1}$ under both environments. Similarly, High heritability $\left(\mathrm{H}^{2}\right)$ under normal and water stress environments was observed for plant height, flag leaf area, tillers plant ${ }^{-1}$, grains spike $^{-1}$ and biological yield plant ${ }^{-1}$.

Keeping in view the overall results of the study, it is recommended that parents Chakwal 86 and Galaxy 2013 having highest general combining ability for various traits under normal and water stress conditions. Similarly crosses B 215 B $1103 \times$ Galaxy 2013, GA $2002 \times 2511$ and ESWYT P $117 \times$ Lasani 2008 being best specific combiners under both conditions can be safely employed for future breeding programs to explore high yielding wheat genotypes under water stress conditions. 


\section{REFERENCES}

[1] Ahmad, M., Munir, M., Ahmad, I., Yousuf, M. (2011): Evaluation of bread wheat genotypes for salinity tolerance under saline field conditions. - African Journal of Biotechnology 10(20): 4086-4092.

[2] Bibi, R., Hussain, S. B., Khan, I. R. (2013): Assessment of combining ability in bread wheat by using line $\times$ tester analysis under moisture stress conditions. - Pak. J. Agri. Sci. 50(1): 111-115.

[3] Dreisigacker, S., Melchinger, A. E., Zhang, P., Ammar, K., Flachenecker, C., Hoisington, D., Warburton, M. L. (2005): Hybrid performance and heterosis in spring bread wheat and their relations to SSR-based genetic distances and coefficients of parentage. Euphytica 144: 51-59.

[4] Ministry of Food, Agriculture and Livestock (2019): Economic Survey of Pakistan 201819. - Ministry of Food, Agriculture and Livestock, Government of Pakistan, Statistical Division (Economic Wing), Islamabad.

[5] Falconer, D. S., Mackay, T. C. (1989): Introduction to Quantitative Genetics. - John Willey and Sons. Inc., New York, pp. 313-320.

[6] FAO (2019): FAO Statistical Database 2019. - Food and Agricultural Organization of the United Nations, Rome.

[7] Fellahi, Z. E. A., Hannachi, A., Bouzerzour, H., Boutekrabt, A. (2013): Line $\times$ tester mating design analysis for grain yield and yield related traits in bread wheat (Triticum aestivum L.). - Int. J. Agron. https://doi.org/10.1155/2013/201851.

[8] Hammad, G., Kashif, M., Munawar, M., Ijaz, U., Raza, M. M., Saleem, M. (2013): Genetic analysis of quantitative yield related traits in spring wheat (Triticum aestivum L.). - Am. Euras. J. Agri. Environ. Sci. 13(9): 1239-1245.

[9] HongBo, S., ZongSuo, L., MingAn, S. (2006): Osmotic regulation of 10 wheat (Triticum aestivum L.) genotypes at soil water deficits. Colloids Surfaces. - Biointerfaces 47: 132139.

[10] Iqbal, M., Navabi, A., Salmon, D. F. (2007): Genetic analysis of lowering and maturity time in high latitude spring wheat: genetic analysis of earliness in spring wheat. Euphytica 154: 207-218.

[11] Jain, S. K., Sastry, E. V. D. (2012): Heterosis and combining ability for grain yield and its contributing traits in bread wheat (Triticum aestivum L.). - Res. Rev. J. Agri. Alli. Sci. 1: 17-22.

[12] Jatav, M., Jatav, S. K., Kandalkar, V. S. (2014): Combining ability and heterosis analysis of morpho-physiological characters in wheat. - Ann. Plant Soil Res. 16(2): 79-83.

[13] Kempthorne, D. (1957): An Introduction of Genetic Statistics. - John Willey and Sons, Inc., New York, pp: 468-473.

[14] Kumar, D., Kumar, A., Kaur, S., Yadav, A. Y. (2018): Combining ability for yield attributing traits in wheat (Triticum aestivum L.). - Journal of Pharmacognosy and Phytochemistry SP1: 2730-2735.

[15] Longin, C. F. H., Mühleisen, J., Maurer, H. P., Zhang, H., Gowda, M., Reif, J. (2012): Hybrid breeding in autogamous cereals. - Theor. Appl. Genet. 125: 1087-1096.

[16] Majeed, S., Sajjad, M., Khan, S. H. (2011): Exploitation of non-additive gene actions of yield traits for hybrid breeding in spring wheat. - J. Agri. and Soc. Sci. 7(4): 131-135.

[17] Mirbahar, A. A., Markhand, G. S., Mahar, A. R., Abro, S. A. (2009): Effect of water stress on yield and yield components of wheat (Triticum aestivum L.) varieties. Pakistan Journal of Botany 41(3): 1303-1310.

[18] Muneer, M. A., Nisa, Z. M. Z., Munir, M. Z., Imran, M., Intikhab, A., Adil, S., Saifullah, N. (2016): Line $\times$ tester analysis for yield contributing morphological traits in Triticum aestivum under drought conditions. - International Journal of Agronomy and Agricultural Research 9(2): 57-64. 
[19] Nawaz, R., Inamullah, H. A., Uddin, S., Iqbal, M. S., Gürsoy, S., Kutbay, H. G., Abdullah, F. (2013): Agro-morphological studies of local wheat varieties for variability and their association with yield related traits. - Pakistan Journal of Botany 45(5): 17011706.

[20] Noorka, I. R., Ullah, T. (2015): Estimation of heterosis, proportional contribution of lines, testers and line $\mathrm{x}$ tester interaction and gene action among different maize hybrids at different water regimes. - Journal of Animal and Plant Sciences 25(6): 1616-1625.

[21] Noorka, I. R., Teixeira da Silva, J. A. (2014): Physical and morphological markers for designing drought-tolerant wheat adapted to climate change. - Pak. J. Argic. Sci. 51(4): 943-952.

[22] Noorka, I. R., Tabassum, S., Afzal, M. (2013): Detection of genotypic variation in response to water stress at seedling stage in escalating selection intensity for rapid evaluation of drought tolerance in wheat breeding. - Pakistan Journal of Botany 35(1): 99-104.

[23] Noorka, I. R., Ullah, T., Khan, Z. I., Heslop-Harrison, P., Ahmed, K., Shahid, A. S. (2020): Genotypic response in maize seedlings growth and re-growth for drought adaptation under diverse irrigation regimes. - Journal of Genetics, Genomics \& Plant Breeding 4(2): 103-113.

[24] Saeed, M., Khalil, I. H., Nayab, D., Anjum, S. A., Tanveer, M. (2016): Combining ability and heritability for yield traits in wheat (Triticum aestivum L.). - Pak. J. Agri. Sci. 53(3): 552-9034.

[25] Salman, S., Khan, S. J., Khan, J., Khan, R. U., Khan, I. (2014): Genetic variability studies in bread wheat (T aestivum L.) accessions. - Pakistan Journal of Agricultural Research 27(1): 01-07.

[26] Sattar, S., Nawaz. B., Tahir, A., Ahmed, A., Naeem, M., Ghouri, M. Z., Jamshaid, M. (2018): Gene action and combining ability analysis of quantitative traits associated with grain yield in wheat under drought stress and normal irrigation conditions. - Global Journal of Bioscience and Biotechnology 7(4): 642-650.

[27] Shabbir, G., Kiran, T., Akram, Z., Tabassum, M. I., Shah, K. N. (2012): Genetics of some biometric traits in bread wheat (Triticum aestivum L.). - J. Agri. Res. 50(4): 457-468.

[28] Singh, A., Kumar, A. (2014): Gene action analysis for yield and yield contributing traits in bread wheat. - International Journal of Basic and Applied Biology 2(1): 17-20.

[29] Srivastava, M. K., Singh, D., Sharma, S. (2012): Combining ability and gene action for seed yield and its components in wheat (Triticum aestivum L.) - Electronic J. Plant Breeding: 3(1) 606-611.

[30] Steel, R. G. D., Torrie, J. H., Dickey, D. A. (1997): Principles and Procedures of Statistics. A Biometrical Approach. 3rd Ed. - McGraw Hill Book Co., New York.

[31] Ullah, T., Noorka, I. R., Heslop, H. (2019): Genetical studies of corn crop to exploit heterosis, proportional contribution and gene action at diverse seasons and water regimes. - Pure Appl. Biol. 8(2): 1359-1373.

[32] Yao, J., Yang, H., Zhou, M., Yang, D., Ma, H. (2014): Inheritance of grain yield and its correlation with yield components in bread wheat (Triticum aestivum L.). - Turk. J. Field Crops 19: 169-174. 